\title{
Biometric testicular and serum testosterone concentration of Brazilian Ponies stallions
}

\author{
Biometria testicular e concentrações séricas de testosterona de garanhões Pôneis da \\ raça Brasileira
}

\author{
RUA, Miguel Alejandro Silva ${ }^{1 *}$; QUIRINO, Celia Raquel ${ }^{1 * *}$; VEJA, Wilder Hernando \\ Ortiz $^{1}$; BARTHOLAZZI JUNIOR, Aylton ${ }^{1}$; BASTOS, Rosemary ${ }^{1}$; MATOS, Luis \\ Fonseca $^{1}$; DAVID, Caroline Marçal Gomes ${ }^{1}$
}

\begin{abstract}
${ }^{1}$ Universidade Estadual do Norte Fluminense, Centro de Ciências e Tecnologias Agropecuárias, Laboratório de Reprodução e Melhoramento Genético Animal, Campos dos Goytacazes, Rio de Janeiro, Brasil.** CNPq researcher.

*Endereço para correspondência: miguelvet-rua@hotmail.com
\end{abstract}

\section{SUMMARY}

Evaluation of the testis size is very important in stallions' selection, since it is an indirect determinant of their reproductive potential. The aim of this study was to evaluate the biometric testicular traits, calculate the volume testicular and analyze the serum testosterone concentration of the stallion. During six months were measured the tests of adults Brazilian Ponies stallions from northern of Rio de Janeiro State, Brazil. The length, the width and the height of the testicles (TL, TW and TH) were measured. From these measurements, the total testicular volume (TTV) was calculated. The serum testosterone concentration was also evaluated. The data were studied by analysis of variance and were calculated the correlations among the traits. The average of the testis biometry were TL $5.8 \pm 0.6 \mathrm{~cm}$; TW $3.8 \pm 0.5$ $\mathrm{cm}$; TH $4.7 \pm 0.4 \mathrm{~cm}$ and $111.2 \pm 27.7$ for TTV. Mean of serum testosterone concentration was $0.89 \pm 0.52 \mathrm{ng} / \mathrm{dl}$. High correlations between biometry testicular traits with testicular volume were observed and low to moderate correlations were observed for testicular traits, testosterone and sperm output. The testis size could be an important trait that assists to the prediction of stallion's reproductive potential of the Brazilian ponies stallions. It is suggested that there would be no fluctuation in serum testosterone concentration in Brazilian ponies stallions that coult afect on its fertility.

Keywords: andrology, horse, reproduction

\section{RESUMO}

Avaliação do tamanho dos testículos é muito importante na seleção de garanhões, uma vez que é um determinante indireto do seu potencial reprodutivo. O objetivo deste estudo foi avaliar as características de biometria testiculares, calcular o volume testicular e analisar a concentração sérica de testosterona de garanhões. Durante seis meses, foram medidos os testículos de garanhões Pôneis da raça Brasileiro adultos, criados no Norte do Estado do Rio de Janeiro, Brasil. O comprimento a largura e a altura dos testículo (TL, TW e TH) foram mensurados. A partir dessas medidas, calculou-se o volume testicular total (TTV). Os dados foram avaliados por análise de variância e foram calculadas as correlações entre as características. A média geral das características de biometria testicular e volume testicular foram: TL $5,8 \pm 0,6 \mathrm{~cm}$; TW $3,8 \pm 0,5 \mathrm{~cm}$; TH 4,7 $\pm 0,4 \mathrm{~cm} \mathrm{e}$ TTV $111.2 \pm 27,7$. A média de concentração sérica de testosterona foi de $0,89 \pm 0,52 \mathrm{ng} / \mathrm{dl}$. Altas correlações foram observadas entre as características de biometria testicular e volume testicular. Baixas a médias correlações entre as características testiculares com produção espermática e com concentração de testosterona foram observadas. O tamanho testicular pode ser uma importante característica que auxilia na predição do potencial reprodutivo do garanhão pôneis da raça Brasileira. Sugere-se que não há variações na concentração sérica de testosterona nos pôneis da raça Brasileira que poderia afetar em sua fertilidade.

Palavras-chave: andrologia, equino, reprodução 


\section{INTRODUCTION}

The national Brazilian Pony breed origin comes from the crossbreed of Shetland from Scotland and Falabella ponies from Argentina. These horses can be used for riding, traction and also used as a pet. Its docility and small stature make the Brazilian Ponies breed a great attraction for riding and equotherapy by children. They are small animals that require a little space to keep them and they are also rustic (ABCMH, 2002).

The Brazilian Pony breed has expanded and has become increasingly important in Brazil, however there is lack of information about the characteristics associated to reproductive efficiency as the testis biometry of the Brazilian Ponies stallions; therefore, it needs for more research, especially for selection the stallions with highest fertility potential.

Among the traits to be evaluated in horses' selection, besides the andrology evaluation, the testicular traits is an important characteristic to be considered (CANISSO et al., 2008). According to McKinnon et al. (2011), testicular measurements are influenced by breed, age and breeding season. The same authors also observed that the volume and testicular size are measurements that are directly related to the daily semen output.

According to Roser (2009), horses are considered a reproductive species of "long days" because of a maximized reproductive capacity during the summer, when daylight increases. Following this increasing, there are increase of testicular volume, sperm production and plasma concentration of testosterone. In Brazil, the breeding season occurs during the months September to April (summer) when the day length has more hours of light comparing to non-breeding season (winter).

In Brazil, there are few studies about the testis size of ponies and serum testosterone concentration. Therefore, the aim of this study was to evaluate the length, the width and the height of the testis as well as testicular volume, serum testosterone concentration and calculate the correlations between these traits in order to have more information that could be used as a criteria of selection of ponies stallions.

\section{MATERIAL E METHODS}

This animal experimentation was performed with the approval of the Comissão de Ética de Uso de Animais (CEUA - UENF) in accordance with the Sociedade Brasileira de Ciência de Animais de Laboratório/Colégio Brasileiro de Experimentação animal (SBCAL/COBEA) with protocol number 245.

Data of nine $(\mathrm{n}=9)$ adults Brazilian Ponies stallions were collected during six months one time a month. The stallions were bred in northern of Rio de Janeiro State, Brazil (Latitude $-21^{\circ}$ $45^{\prime} 15^{\prime}$, Longitude $-41^{\circ} 19^{\prime} 28^{\prime}, 13$ meters above sea level).

The study was conducted during the breeding season (BS) (December, March, April) and during the nonbreeding season (NBS) (May, August and September). In the north of Rio de Janeiro State, Brazil, the BS occurs in spring and summer from October to April and the nBS occurs in fall and winter from May to September (RUA et al., 2016).

During the experimental period, the stallions were maintained in an individual boxes with $3 \times 4 \mathrm{~m}$ bedded 
with straws. The stallions were fed with pellet supplement (Equitec ${ }^{\circledR}$, Brazil) with $12 \%$ of crude protein, $15 \%$ fibrous fraction and $20 \mathrm{~g} / \mathrm{kg}$ fats and hay twice per day. Water and mineral salt were available ad libitum. During the experiment the stallions were not take to moderate or severe exercises. They were allowed to stay in padoock $\left(150 \mathrm{~m}^{2}\right)$ during one hour a day.

Prior to experimentation, the stallions underwent to a soundness breeding examination and semen collection were performed for five consecutive days to stabilize the extra-gonadal sperm reserves.

All animals presented good body condition during the experiment and once a month measurements of the testis were taken, as well as semen collection and blood samples for testosterone serum concentration, on the day that the stallions underwent a breeding soundness examination.

After the clinical examination, the testis were measured with a caliper: the left testicular length; the right testicular length were measured from the cranial to the caudal edge of the testis; the left testicular width and the right testicular width were measured from lateral to lateral of each testicle; the left testicular height and the right testicular height were measured from the ventral to dorsum of each testicle. Preliminary analysis showed that there was no difference between the left and the right testicles traits $(p>0.05)$. Therefore the means between left and right testicles were calculated, then only the testicular length average (TL), testicular width average (TW) and testicular height average $(\mathrm{TH})$ were considered for the final analysis.

The testicular volume (TV) was calculated using the formula suggested for Love et al. (1991): $\mathrm{TV}_{\mathrm{L} \text { or } \mathrm{R}}=4 / 3 \pi$ $(\mathrm{TL} / 2 \times \mathrm{TW} / 2 \times \mathrm{TH} / 2)$, where $\pi=3.14$;
$\mathrm{TL}=$ testicular length; $\mathrm{TW}=$ testicular width and $\mathrm{TH}=$ testicular height. The total testicular volume was calculated with: $\mathrm{TTV}=\mathrm{TV}_{\mathrm{L}}+\mathrm{TV}_{\mathrm{R}}$.

Semen was collected using an artificial vagina (Botupharma ${ }^{\circledR}$ Botucatu, Brazil) and a mare in estrus was used to stimulate the stallions to perform mount and ejaculation.

The collection of semen was made for six times of each stallion with an interval of 30 days, and the traits evaluated were: seminal volume gel free (Vol $\mathrm{ml})$ and spermatozoal concentration (Conc).

Serum testosterone concentration were analyzed from blood samples from each stallion one a month, collected in the morning using tubes (Vacutainer ${ }^{\circledR} \mathrm{BD}$ Diagnostics, New Jersey, USA) without EDTA. The samples were collected and transported to the laboratory in a Styrofam ${ }^{\circledR}$ box (Sunrise, Florida, USA) after being placed on ice from $20 \mathrm{~min}$. testosterone concentratios were determined through use of a solid-phase radioimmunoassay (RIA) using a commercial diagnostic kit from Immunotech $^{\circledR} \quad$ (São Paulo, Brazil) Beckman Coulter Laboratories (Marsellie, France).

Analysis of variance of testicular characteristics was performed to verify effect of month of evaluation (ME) on the TL, TL and TW; performed with MIXED procedure (SAS, 2009). The LS means were compared using the test with $5 \%$ probability.

The final model was $\mathrm{Y}_{\mathrm{jl}}=\mu+\mathrm{ME}_{\mathrm{j}}+\mathrm{e}_{\mathrm{j} 1}$; Where:

$\mathrm{Y}_{\mathrm{j} 1}=$ dependent variable (TL, TL and TW);

$\mu=$ overall mean, associated with the dependent variable;

$\mathrm{ME}_{\mathrm{j}}=$ effect of the jth month of evaluation;

$\mathrm{e}_{\mathrm{jl}}=$ random residue associated with each observation. 
The CORR procedure (SAS, 2009) was used to calculate the simple correlations between traits.

\section{RESULTS AND DISCUSSION}

Previously the testicular biometry were evaluated (left and right separately) and there were no differences between left and right $(p>0.05)$. However, in large horses breed there has been reported a tendency for the left testicle to be large than the right testicle (BORGES et al., 2010). Hafez and Hafez (2004) also observed the same, suggesting that this occurs due to the earlier development of the left testicle in relation to the right testicle.

In addition, the Brazilian Ponies are animals of small size and have their testis smaller than stallions of large breed as Quarter Horses and Mangalarga Marchador breed. The testicles of the Brazilian Ponies stallions are smaller comparing with the testicles of the Mangalarga Marchador stallions in a proportions of $65.0 \%$ for TTV.

In this study all stallions were adults, then differences of age in testicular traits could not be observed. However, Aurich (2005) related that the size and concentrations of the Sertoli cells and Leyding cells as well as the spermatogenesis capacity of the testicles, increase in the stallions' testis until four to five years of age.

The LSmeans of the measurements of the testis were $5.8 \pm 0.6 \mathrm{~cm}$ for TL; 3.8 $\pm 0.5 \mathrm{~cm}$ for $\mathrm{TW} ; 4.7 \pm 0.4 \mathrm{~cm}$ for $\mathrm{TH}$. The results observed in this study were similar to the results observed by Tarouco et al. (2011) who made a study with four Brazilian Pony breed created in southern Brazil (5.5 cm for TL; 3.5 $\mathrm{cm}$ for TW; $4.5 \mathrm{~cm}$ for $\mathrm{TH}$ ).

Month of evaluation did not affected the testicular trsits ( $p>0.05)$. Except for TH $(p<0.05)$ that was low in December and August (Table 1).

Table 1. LSmeans and standard deviations of the testicular length (TL); testicular width (TW) testicular height (TH) and total testicular volume (TTV) of Brazilian Ponies stallions, according to the month of evaluation, in the Rio de Janeiro state, Brazil

\begin{tabular}{lcccc}
\hline Month/Season & TL $(\mathrm{cm})$ & TW $(\mathrm{cm})$ & TH $(\mathrm{cm})$ & TTV $(\mathrm{cm} 3)$ \\
\hline December-BS & $5.8 \pm 0.7^{\mathrm{a}}$ & $3.5 \pm 0.5^{\mathrm{a}}$ & $4.2 \pm 0.3^{\mathrm{b}}$ & $93,9 \pm 30,3^{\mathrm{a}}$ \\
March-BS & $6.0 \pm 0.7^{\mathrm{a}}$ & $3.8 \pm 0.4^{\mathrm{a}}$ & $5.0 \pm 0.4^{\mathrm{a}}$ & $123,0 \pm 39,4^{\mathrm{a}}$ \\
April-BS & $6.0 \pm 0.6^{\mathrm{a}}$ & $3.8 \pm 0.4^{\mathrm{a}}$ & $5.0 \pm 0.4^{\mathrm{a}}$ & $123,0 \pm 39,4^{\mathrm{a}}$ \\
May-NBS & $6.0 \pm 0.3^{\mathrm{a}}$ & $3.9 \pm 0.3^{\mathrm{a}}$ & $4.8 \pm 0.2^{\mathrm{a}}$ & $119,5 \pm 18,4^{\mathrm{a}}$ \\
August-NBS & $5.8 \pm 0.6^{\mathrm{a}}$ & $3.7 \pm 0.4^{\mathrm{a}}$ & $3.9 \pm 0.5^{\mathrm{b}}$ & $90,0 \pm 25,9^{\mathrm{a}}$ \\
September-NBS & $5.6 \pm 0.6^{\mathrm{a}}$ & $4.1 \pm 0.4^{\mathrm{a}}$ & $4.7 \pm 0.4^{\mathrm{a}}$ & $117,2 \pm 30,4^{\mathrm{a}}$ \\
\hline
\end{tabular}

Equal letters in the same column don't show statistical difference between the means $(\mathrm{p}>0.05)$.

$\mathrm{BS}=$ Breeding season, NBS $=$ non-breeding season.

There was no effect of the months of evaluation on TTV $(p>0.05)$. Variation was not observed on the means for these traits neither.

In northern of Rio de Janeiro the temperatures are medium to high throughout the year $\left(25-32^{\circ} \mathrm{C}\right)$ (RUA et al., 2013) which may contribute to not detect differences in testicular measures in ponies stallions in different months of evaluations, as well as there is little difference in photoperiod in this 
region either. Although we observed effect $(p<0.05)$ of the months of evaluation on TH and the means of this characteristic varied through months of evaluation, there was no effect on the TTV. The means of this trait also did not varied through months of evaluations; this would be associated with the similar average of temperature in different months of the year, and the weather of this region is tropical and with few rain, then environmental effect did not affected most of testicular traits.

Effect of month of evaluation was observed on the characteristics of spermatozoa concentration and serum testosterone concentration $(\mathrm{p}<0.05)$.

McKinnon et al. (2011) studying the testis size of stallions aged 4-20 years reported that stallions are seasonal breeders and their testicular characteristics undergo changes during the year. The authors reported that are an increase in testicular size during the breeding season, observing an increase in the number of Leyding cells, Sertoli cells, spermatids and this increased the daily sperm production. How the photoperiod is considered one of the most important factor that cause influence in testicular size (McKINNON et al., 2011), in this study the little variation in photoperiod could be considered as a factor which we did not observed variations in testicles size of the Brazilian Ponies stallions. Freitas (2010) evaluated the testis size of Mangalarga Marchador stallions, in Minas Gerais, state, Brazil and also noted that there was no difference in total testicular volume between seasons. As in the present study no difference were observed in testicular size during the months in which the measurements were made, it is suggested that the Brazilian Ponies stallions evaluated would be adapted to the climatic and seasonal conditions of the northern of Rio de Janeiro state, where the climate is predominantly warm throughout the year and differences in photoperiod are small in this region that is near to the sea. The small difference in photoperiod throughout the testosterone and proliferation and the number of cells present in testicular parenchyma of these animals would not suffer major changes. The concentration of spermatozoa varied among months (Table 2) different from the testicular traits that did not varied among months. Table 3 shows the correlations among the testis traits, testis volume, spermatozoa concentration and serum testosterone concentration Brazilian Ponies stallions. In general, all testicular traits showed high correlations among themselves.

Table 2. LSmeans and standard deviation of spermatozoa concentration and serum testosterone concentration of Brazilian Ponies stallions.

\begin{tabular}{lcc}
\hline Month/Season & Concentration $\left(\times 10^{6} / \mathrm{ml}\right)$ & Testosterone $(\mathrm{ng} / \mathrm{ml})$ \\
\hline December-BS & $389.3 \pm 235.0^{\mathrm{ab}}$ & $1.4 \pm 0.3^{\mathrm{a}}$ \\
March-BS & $572.5 \pm 247.8^{\mathrm{a}}$ & - \\
April-BS & $273.1 \pm 112.1^{\mathrm{ab}}$ & $0.4 \pm 0.1^{\mathrm{a}}$ \\
May-NBS & $383.1 \pm 153.9^{\mathrm{a}}$ & $0.9 \pm 0.7^{\mathrm{a}}$ \\
August-NBS & $500.2 \pm 237.8^{\mathrm{ab}}$ & $0.7 \pm 0.2^{\mathrm{a}}$ \\
September-NBS & - & $0.8 \pm 0.5^{\mathrm{a}}$ \\
\hline
\end{tabular}

Equal letters in the same column don't show statistical difference between the means ( $p>0.05)$.

$\mathrm{BS}=$ Breeding season, NBS $=$ non-breeding season. 
Table 3. Correlation among testicular traits, testosterone, spermatozoa concentration and total number of spermatozoa of Brazilian Ponies Breed stallions of the Rio de Janeiro state, Brazil

\begin{tabular}{lcccccc}
\hline & TTV & Conc & Test & TL & TW & TH \\
\hline TTV & - & - & - & - & - & - \\
Conc & 0,23 & - & - & - & - & - \\
Test & 0,20 & 0,16 & - & - & - & - \\
TL & $0,81^{* *}$ & 0,14 & 0,08 & - & - & - \\
TW & $0,86^{* *}$ & 0,04 & 0,20 & $0,55^{*}$ & - & - \\
TH & $0,85^{* *}$ & $-0,04$ & 0,09 & $0,55^{* *}$ & $0,64^{* *}$ & - \\
\hline
\end{tabular}

$\mathrm{TTV}=$ total testicular volume; Conc $=$ spermatozoa concentration; Test $=$ testosterone; $\mathrm{TL}=$ testicular length; TW = testicular width, $(\mathrm{TH})$ Testicular height.

* Significant $(\mathrm{p}<0,05),{ }^{* *}$ Highly significant $(\mathrm{p}<0,001)$.

The testis were always proportional in relation to the length, width and height, as well as volume. As the values of the characteristics of testis size are used to calculate the TTV, it could explain the high correlation observed among TL, TW and TH with TTV. Then, from the measurement of the three testis traits (length, width and height) one of this would estimate the TTV or if the stallion have a testicular size normal and similar to the breed pattern.

Spermatozoa concentration and serum testosterone concentration showed low and moderate correlations with testicular characteristics. McKinnon et al. (2011) related that there is correlation between testicular volume (testicular parenchyma) and sperm output and between testicular volume and testosterone. The quantity of testicular parenchyma is proportional with the amount of Leyding cells that are involving testosterone production and Sertoli cells that are involved in regulating formation of spermatozoa.

Regarding the testis traits, there are lack of information on literature about Brazilin ponies stallions, however there were few variation among animals and during the experimentation.

The testis size could be an important trait that assists to the prediction of stallion's reproductive potential of the Brazilian ponies stallions. It is suggested that there would be no fluctuation in hormonal stimulation in Brazilian ponies stallions that coult afect on its fertility.

\section{ACKNOWLEDGMENTS}

This work was supported by the Coordenação de Aperfeiçoamento de Pessoal de Nivel Superior (Capes) and by the fellowshep Conselho Nacional de Desenvolvimento Scientífico e Tecnológico $(\mathrm{CNPq})$ Brazil.

\section{REFERENCES}

\section{ABCMH. Associação Brasileira dos} Criadores de Mini-Horse. Disponível em:

$<\mathrm{http}$ ://www.ponei.com.br/sua_origem. htm>. Acesso em: 26 maio. 2016.

\section{AURICH, C. Reproduktionsmedizin}

beim pferd. physiologie der fortplazungsfunkitionen beim hengst. 13. ed. Stuttgart: Parey Verlag, 2005. p.243-245. 
BORGES, G. S.; MELO, M. I. V; MAMBRINI, J. V. M.; SNOECK, P. P. $\mathrm{N}$. Biometria testicular de garanhões da raça campolina. Boletim de Indústria Animal, v.67, p.157-162, 2010.

CANISSO, I. F.; SOUZA, F. A.; CARVALHO, G. R.; GUIMARÃES, J. D.; SILVA, E. C.; LIMA, A. L. Alguns aspectos fundamentais do exame clínico andrológico de jumentos (Equus asinus). Revista Brasileira de Reprodução Animal, v.32, n.4, p.233239, 2008.

FREITAS, B. W. de. Parâmetros fisiológicos e seminais de garanhões da raça mangalarga marchador na região da zona da mata mineira no decorrer das estações climáticas. 2010. 72p. Dissertação (Mestrado) Universidade Federal de Viçosa, Viçosa.

HAFEZ, E.S.E.; HAFEZ, B.

Reprodução animal. 7.ed. São Paulo: Manole, 2004.

LOVE, C.C.; GARCIA, M.C.; RIERA, F.R.; KENNEY, R.M. Evaluation of measures taken by ultrasonography and caliper to estimate testicular volume and predict daily sperm output in the stallion. Journal of Reproductive Fertility Supplement, v.44, p.99-105, 1991.

MCKINNON, A.O.; SQUIRES, E.L.; VAALA, W.E.; VARNER, D.D.

Equine reproduction. 2.ed. Ames: Blackwell Publishing Ltd, 2011. v. 1

ROSER, J.F. Reproductive endocrinology of the stallion. In: SAMPER, J. C. (Ed.). Equine Breeding Management and Artificial Insemination. Philadelphia: Sounders, 2009. p. 17-31.
RUA, M.A.S.; QUIRINO, C.R.; BARTHOLAZZI JUNIOR, A.; SANTORO, P.N.; BASTOS, R.; RIBEIRO, M. da S.; MATOS, L. F.; VEGA, W. H. O. Evaluation of the breeding behavior of Brazilian Pony stallions. Animal Reproduction Science, v.172, p.137-142, 2016.

RUA, M.A.S.; QUIRINO, C.R.; PACHECO, A.; VEGA, W.H.O.; RIBEIRO, M.S.; MATOS, L.F. Caracterização fisiológica e seminal de pôneis do Norte do Estado do Rio de Janeiro-Brasil. Actas Iberoamericanas de Conservación Animal, v.3, p.5158, 2013.

SAS. Statistical analyses system. Cary, NC, USAInstitute Inc., 2009.

TAROUCO, A.K.; FREITAS, CC.de.; NEVES, A.P.; TAROUCO, J.U.; RECH, C.L. de S.; GREGORY, R.M.; MATTOS, R.C. Condição sociossexual de uma população de pôneis da raça Brasileira. Revista de Etologia, v.10, n.1, p.34-44, 2011.

Data de recebimento: 06/05/2016

Data de aprovação: 10/08/2016 